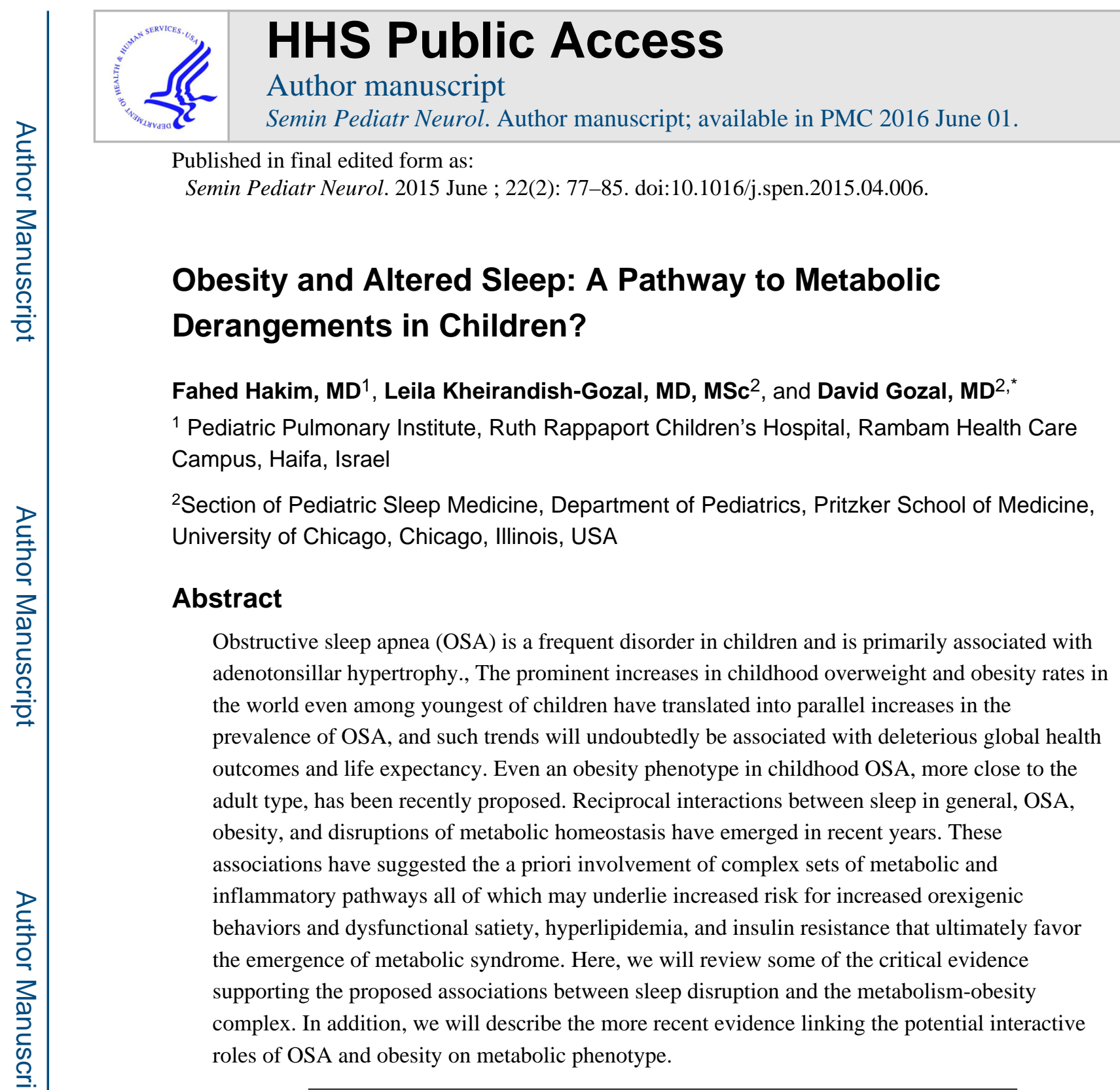

Over the last several decades, the prevalence and severity of overweight and obesity in children and adolescents have increased and led to the term "globesity". Some degree of deceleration in such trends has thankfully occurred most recently in several countries, and likely reflects the results of multiple public-driven efforts to reduce this epidemic. However, the overall world view is that the number of obese children will continue to rise and reach even more worrisome rates than current (Figure 1) [1-8]. Moreover, in a recently published review by Lobstein and colleagues [9], the authors concluded that in the USA, the average weight of a child has risen by more than $5 \mathrm{~kg}$ over the last three decades, and a third of the country's children are overweight or obese. Furthermore, some low-income and middle-

(C) 2015 Published by Elsevier Inc.

*Corresponding author: David Gozal, M.D., Department of Pediatrics, The University of Chicago, KCBD, Room 4100, 900 E. 57th Street, Mailbox 4, Chicago, IL, 60637. Tel: (773) 834-1483; (773) 702-4523 - FAX; dgozal@uchicago.edu.

Publisher's Disclaimer: This is a PDF file of an unedited manuscript that has been accepted for publication. As a service to our customers we are providing this early version of the manuscript. The manuscript will undergo copyediting, typesetting, and review of the resulting proof before it is published in its final citable form. Please note that during the production process errors may be discovered which could affect the content, and all legal disclaimers that apply to the journal pertain. 
income countries have reported similar or more rapid rises in child obesity, despite continuing high levels of undernutrition. Indeed, a rising prevalence of obesity in children from 42 million in 2013 to over 70 million in 2025 is anticipated in the African continent alone (see: http://www.who.int/end-childhood-obesity/facts/en/).

As a consequence of the increases in prevalence and severity of obesity, a corresponding increase in the prevalence of obesity-associated morbidities has occurred, and previously rare conditions such as the metabolic syndrome, cardiovascular disease, non-alcoholic liver steatosis, depression, and decreased quality of life have all begun to emerge, even among the youngest of children [10-15]. Importantly, childhood obesity does not only affect children when they are young, but also seems to impose long-lasting sequelae. For example, when comparing obese with non-obese children who were followed for a 22-year period, the presence of obesity alone independently predicted the long-term risks of diabetes or adulthood obesity [16].

In parallel with such alarming state of affairs, recent years, evidence has also started to emerge on the potentially important role of sleep and sleep disorders in either promoting, or aggravating obesity, and its attendant metabolic and cardiorespiratory complications.

Conversely, the role of obesity in the pathophysiology of sleep disorders has also been advanced. Here, we will therefore review the evidence on the bilateral and mutual interactions linking sleep and disruption of metabolic homeostasis in children.

\section{Obesity and Sleep}

Societies in general, and more particularly technology-driven societies have rapidly transformed, and generated an increasingly demanding life pace [1]. This 24/7 lifestyle has in turn substantially altered sleep patterns and duration, not only in working adults but even in toddlers and children $[17,18]$. The progressive decrements in sleep duration and sleep regularity have been accompanied by the aforementioned surge in the prevalence of childhood obesity, especially in the pubertal and post-pubertal period [19, 20]. In the last decade, arguments and evidence supporting a strong association between sleep duration and obesity have been put forth and corroborated across multiple studies in diverse populations from around the globe [21-26]. Concurrent with such epidemiological evidence, some of the biological pathways that underlie the strong association between sleep integrity and metabolic function have been partially elucidated. Such evidence would support that inadequate amounts of sleep will lead to endoplasmic reticulum stress in hypothalamic neurons, to alterations in some of the neuropeptides that regulate appetite, such as increased levels of ghrelin, reduced levels of leptin, and reduced central biological activity of orexin, all of which would then converge to increase food intake and reduce satiety [27-29] [30]. Under particular circumstances, the correlation of insufficient sleep with food desire and screen time emerges as being particularly prominent, especially among children and adolescents [23, 31-33]. Despite aforementioned comments, we should also note that although the overall data are supportive of an association between short sleep duration and increased risk for obesity, some studies have been somewhat conflictive for any of the age groups examined. For example, while multiple studies have identified a significant contribution of sleep duration to obesity risk in adults [34-37] such findings have not been 
consistently reported [38], and could reflect either methodological issues in defining short sleep as compared to insufficient sleep [39]. In addition, multiple confounding factors that play a role in the propensity for obesity, are likely to start early in life, such that the associations between sleep and obesity may be lost later on when the surveys are conducted [40]. Furthermore, in a cross sectional and longitudinal study, Chaput and colleagues found that only those subjects manifesting short sleep duration, high disinhibition eating behavior, and low dietary calcium intake had significantly higher BMI compared to the reference category in both sexes. Indeed, over the 6-year follow-up period, these high-risk adult subjects were significantly more likely to gain weight and develop obesity [41] [42] [43].

Thus, to further clarify these issues, intervention trials aiming to establish whether prolongation of sleep will improve metabolic function and promote reduced weight gain, or even weight loss, have been initiated [44]. In children, a recent meta-analysis of the literature indicates that the strength of the association between sleep duration and obesity may actually be stronger in children and adolescents, and declines over time [38]; however, such association is not always present even in adolescents [45, 46]. In a longitudinal study, Caspedes and colleagues followed a cohort of children from 6 month till the age of seven, and found that chronic insufficient sleep from infancy to school-age was associated with higher mid-childhood metabolic risk. The best predictive risk score was derived from the mean of waist circumference, systolic blood pressure, HDL cholesterol, log-transformed triglycerides and HOMA-IR, and the independent contribution of sleep to the model was readily detectable [47]. Furthermore, some degree of predisposition for the existence of such association has been advanced, since sleep-associated changes in BMI appear to be primarily affecting those children whose BMI is already elevated [48]. Moreover, when looking at accompanying morbidities, sleep duration seems to have a major influence on the cardiovascular and cognitive aspects of those co-morbidities. In their most recent publication, Iglayreger and colleagues have shown that sleep duration inversely predicts cardiometabolic risk in obese adolescents, even when controlling for various measures of physical activity, anthropometry, and adiposity [49]. Conversely, longer sleep duration was also significantly associated with lower ambulatory systolic and diastolic blood pressure [50].

Despite the rather high number of studies exploring the sleep-obesity association the most important limitation of the vast majority of these studies in children is that they relied on subjective estimates of sleep duration [24, 51, 52]. Furthermore, the impact of the variability of sleep schedules on BMI trajectories was not explored, and the effects of specific sleep patterns on metabolic homeostasis in children are unknown, and somewhat precluded from investigation due to ethical concerns. Studies interrelating sleep duration and obesity are further hampered by the obstacles and inherent challenges of measuring sleep duration in a natural environment, such that most studies thus far have relied on parental reports. Parental reports however, will generally 'overestimate' the sleep duration of their children [53-55]. Out of all published studies, only 3 studies used actigraphy to record sleep but 2 of those limited such recordings to $24 \mathrm{hr}[21,54]$. We conducted a prospective and large scale crosssectional study in which we found that in $>300$ community-dwelling healthy pre-pubertal children assessed with actigraphy for a week, sleep regularity was more prominently associated with both metabolic (insulin resistance) and inflammation (high-sensitivity C- 
reactive protein) than sleep duration, even if a measurable effect was also detectable for those children with restricted sleep [56] . Thus, the scarcity of objective measures and of longitudinal studies and the disparity in age ranges across studies and within studies further generate another layer of complexities that restrict our ability to draw firm conclusions. For example, using similar literature review methodologies, Cappuccio et al. [53] approached the potential confounders in existing studies, e.g., gender proportions, sample size, sampling but applied a very different cut-off for defining 'short' sleep in children compared to the cutoff employed by Chen et al., i.e., $₫ 10$ hours per night [21].

As with adults, the heterogeneity of the published associations between sleep duration and obesity reported in children range from absence of any association, to a negative linear trend or to an inverted U-shaped relationship. Such discrepancies may simply reflect sampling bias or over-controlling for certain variables. Notwithstanding, sleep duration and body weight are determined by a multitude of factors, including sociodemographic, socioeconomic, familial (e.g., family structure, overweight parent) and individual (e.g., health behavior, health status) [57, 58], and these factors need to be assessed and incorporated to enable more accurate adjustments for confounders and covariates in the interpretation of any future findings. Regardless of aforementioned limitations, the strength of the association between sleep duration with BMI is about 1.5 to 2-fold increase in the probability that decreased sleep duration will be present in children with increased BMI, will relative risks ranging from 1.15 to 11 ) [59, 60]. In this context, attempts to extend sleep in children are likely to fail, because both sleep regularity and sleep duration are established and relatively stable across long periods of time during childhood [61].

Obesity can lead to changes in metabolic profile by eliciting the accumulation of adipose tissue, a complex and active organ that is composed of connective tissue, adipocytes, and the subcutaneous vascular fraction, the latter containing cells of multiple lineages, such as endothelial cells, adipocyte progenitors, $\mathrm{T}$ cell lymphocytes, and macrophages. With increased adipocyte number and size, changes in adipocyte-derived hormones and in regional tissue perfusion and oxygenation lead to increased local oxidative stress and promote the recruitment of innate inflammatory cells and activation of complex mechanistic cascades abutting in major alterations in adipose tissue function. The conglomerate results of these events invoke the onset of insulin resistance and other metabolic derangements within adipose tissues. However, the latter perturbations are not restricted to adipose tissue, but further propagate and induce structural and metabolic alterations in other organs, including skeletal muscle and liver. Indeed, obesity is closely linked to fat storage in liver, and is nowadays considered as a major risk factor for the development of fatty liver disease [62]. Thus, the effects of sleep patterns on BMI z-score and metabolic markers could be difficult to reverse if interventions are not implemented early in life. Taking all those confounders in consideration, Bonuck and colleagues reexamined the effect of sleep disordered breathing (SDB) and sleep duration in a large cohort of children who was longitudinally monitored for 15 years; they found that both SDB and short sleep duration significantly and independently increased the odds of becoming overweight over time. Those findings underscore the potential importance of early identification and remediation of any sleep disturbance, as minimal as it may seem, as a potentially viable strategic approach for reducing childhood obesity. [63]. In summary, identification of children at risk during infancy and early 
childhood by periodic assessments of sleep duration, regularity or onset of sleep disorders, along with prospective interventions aiming to prolong and regularize sleep in such children should provide us with more definitive answers as to the role of sleep in the context of BMI regulation and metabolic homeostasis during the formative childhood years.

\section{Obesity and Obstructive Sleep Apnea Syndrome: Bad, Bad, and "Badder"}

Childhood obstructive sleep apnea syndrome (OSAS) has now become widely acknowledged as a highly prevalent disorder affecting up to $5 \%$ of all children [64, 65], and associated with potentially serious clinical consequences. Considerable insights into the nature and frequency of such morbidities have emerged in the last 2 decades, and their underlying mechanisms [66-68] [69] [70, 71]. In parallel, the classic presentation of children with OSA as children with adenotonsillar hypertrophy and failure to thrive has now been widely and extensively replaced by a preponderance of patients being either overweight or obese [72]. OSA in children is characterized by recurrent events of partial or complete upper airway obstruction during sleep, resulting in disruption of normal gas exchange (intermittent hypoxia and hypercapnia) and sleep fragmentation. The clinical spectrum of obstructive sleep-disordered breathing includes frank OSA of varying severity, the upper airway resistance syndrome (traditionally associated with low frequency of obstructive apneic events and globally preserved normal oxygenation patterns, but evidence for increased respiratory-related arousals, i.e., sleep fragmentation), and at the low end of the severity spectrum, a condition that has been termed either primary or habitual snoring (i.e., habitual snoring in the absence of apneas, gas exchange abnormalities and/or disruption of sleep architecture). The prevalence of habitual snoring is much higher than that of frank OSA with ratios of 5:1 across most population studies [73-76]. In the vast majority of cases of OSA in children, hypertrophic tonsils and adenoids in the upper airway play a major role [77], that requires however the concurrent presence of alterations in structural and anatomical characteristics, protective reflexes and neuromuscular abnormalities of the upper airway. Thus, pediatric OSA is more common in those children with a positive family history of OSA, children with allergy, children born prematurely, in African American children, and in children with chronic upper and lower respiratory tract diseases [78-82].

Among the many risk factors of OSA in children, there is no doubt that obesity is by far the most important [83]. In a case-control study design, Redline and colleagues examined risk factors for sleep disordered breathing in children aged 2-18 years, and found that the risk among obese children was increased 4-5 fold [84]. More recently, a study by the same research group reported that obesity, but not habitual snoring, in middle childhood predicted adolescent OSAS, thereby suggesting that screening, preventing, and treating obesity in childhood should alleviate the risk of OSA [85]. Similar trends demonstrating increased risk of OSA among obese and overweight children have been reported worldwide [86-94]. Hence, childhood obesity is definitely associated with a higher risk for development of OSA.

In the context of obesity, upper airway narrowing and increased collapsibility could result from fatty infiltration of upper airway structures and tongue, and subcutaneous fat deposits in the anterior and lateral cervical regions also exerting collapsing forces $[95,96]$. Obesity 
may also affect ventilatory capacity through mass loading of the respiratory system [97]. Increased adipose tissue in the abdominal wall and cavity as well as surrounding the thorax increases the global respiratory load, and reduces intra-thoracic volumes and diaphragm excursion, particularly when in the supine position, all of which may result in decreased oxygen reserve and increased work of breathing during sleep. Finally, obesity can be accompanied by poor quality sleep, which may raise the threshold for arousal and therefore prolong the duration of upper airway collapse and its consequences [98].

Conversely, the presence of OSA could promote or aggravate obesity and associated morbidities. OSA is associated with daytime sleepiness [99-102] and sleepiness will promote physical inactivity [103], particularly in those children at risk for obesity, such that it should not be surprising that the degree of daytime sleepiness is exaggerated in obese children with OSA [104]. There is also compelling evidence that OSA promotes the initiation and propagation of both localized and systemic inflammatory processes, such that similar to obesity, OSA is currently viewed as a chronic low-grade inflammatory disease [105-112], In this setting, OSA and obesity may interact and potentiate each other and thus amplify their adverse consequences [113-117]. Recently, in a community based study we aimed to examine the effects of adenotonsillectomy in obese children with polysomnographically diagnosed OSAS, on plasma levels of inflammatory and metabolic markers including interleukin-6 (IL-6), IL-18, plasminogen activator inhibitor-1 (PAI-1), monocyte chemoattractant protein-1 (MCP-1), matrix metalloproteinase-(MMP-9), adiponectin, apelin $\mathrm{C}$, leptin and osteocrin. We found overall significant decreases in MCP-1, PAI-1, MMP-9, IL-18 and IL-6, and increases in adropin and osteocrin plasma concentrations occurring after surgery and normalization of the polysomnography, reflecting the reversibility of the inflammatory activity after OSA treatment [118]. The same trends were also found when measuring similar markers in obese children with OSA, compared to obese non-OSA children [119]. The restricted cluster of systemic inflammatory changes further indicates the importance of treatment of OSA to prevent the comorbidity effects of obesity and sleep apnea. [118]. Moreover, another inflammatory connection between obesity and sleep apnea has been recently explored: the gut microbiome. This uniquely important ecological community is not only a major homeostatic regulator, but if perturbed may change its composition and lead to increased translocation of bacterial lipopolysaccharides (LPS) across the gut epithelium into the systemic circulation. Under such circumstances, altered gut microbiota could lead to obesity and metabolic dysfunction [120-122]. Similarly, gut microbiota could be perturbed by the presence of OSA and trigger inflammation [123]. LPS-binding protein (LBP) serves as a surrogate marker of underlying low-grade endotoxemia by LPS from the gut. Recently, a controlled study compared the levels of plasma LBP in 219 obese and non-obese participants, the non-obese controls (no OSA) had the lowest levels of LBP, and the presence of obesity without OSA was associated with significant LBP increases. Nevertheless, non-obese children with OSA exhibited increased LBP levels, with obese children with OSA demonstrating the highest LBP levels of all four groups. Furthermore, LBP was independently associated with body mass index and with measures of OSA severity as well as with metabolic dysfunction, particularly insulin resistance as indicated by the homeostasis model assessment of insulin resistance [124]. Those findings prompt us to postulate that disrupted sleep and other factors facilitating 
obesity such as a high-fat diet may disrupt the gut microbiome and lead to increased systemic LPS levels with resultant inflammation, promoting downstream metabolic dysfunction .

Although the bidirectional interactions between OSA and obesity appear to be irrefutable, well-controlled interventional trials aiming to assess the implications of treating one of the disorders to ameliorate the other are only starting to emerge. There is now little doubt that the usual treatment of OSA, i.e., surgical adenotonsillectomy, is fraught with a much higher failure rate in obese children $[125,126]$, while preliminary evidence would suggest that weight loss is associated with beneficial effects on OSA severity [93]. However, the impact of treating OSA on obesity propensity or on metabolic dysfunction is yet to be fully explored.

\section{Sleep, Sleep Apnea, Obesity, Cognition and Behavior}

Beyond the metabolic consequences of altered sleep and obesity interactions reviewed above, there is an overlapping issue that merits short mention. For example, obese children are at high risk for attention deficit hyperactivity disorder (ADHD) [127-129]. Similarly, obesity has been implicated in reduced cognitive performance in children [130].

Coincidentally, we showed over 15 years ago that OSA is associated with reduced academic performance that can be long-lasting if left untreated [131, 132], and further uncovered substantial associations between sleep disorders such as OSA or disrupted sleep and behavioral and cognitive functioning that appear to include BMI as a significant component of a mediation model [133]. Thus, complex relationships and interdependencies have emerged between behavioral pathologies resembling ADHD as well as neurocognitive deficits and both sleep restriction, sleep disorders (e.g., OSA) and obesity [134-138]. These areas clearly need to be incorporated into the metabolic implications of sleep, particularly when considering that impulsivity may lead to a propensity for eating disorders or obesogenic eating patterns [139].

\section{Acknowledgements}

DG and LKG are supported by National Institutes of Health grant HL-65270.

\section{References}

1. Lobstein T, Baur L, Uauy R. Obesity in children and young people: a crisis in public health. Obes Rev. 2004; 5(Suppl 1):4-104. [PubMed: 15096099]

2. Magarey AM, Daniels LA, Boulton TJ. Prevalence of overweight and obesity in Australian children and adolescents: reassessment of 1985 and 1995 data against new standard international definitions. Med J Aust. 2001; 174:561-4. [PubMed: 11453327]

3. Oza-Frank R, Hade EM, Norton A, Scarpitti H, Conrey EJ. Trends in body mass index among Ohio's third-grade children: 2004-2005 to 2009-2010. J Acad Nutr Diet. 2013; 113:440-6. [PubMed: 23438495]

4. Smith SM, Craig LC, Raja AE, McNeill G, Turner SW. Growing up before growing out: secular trends in height, weight and obesity in 5--6-year-old children born between 1970 and 2006. Arch Dis Child. 2013; 98:269-73. [PubMed: 23413314] 
5. Broyles S, Katzmarzyk PT, Srinivasan SR, Chen W, Bouchard C, Freedman DS, et al. The pediatric obesity epidemic continues unabated in Bogalusa, Louisiana. Pediatrics. 2010; 125:900-5. [PubMed: 20368311]

6. Claire Wang Y, Gortmaker SL, Taveras EM. Trends and racial/ethnic disparities in severe obesity among US children and adolescents, 1976-2006. Int J Pediatr Obes. 2011; 6:12-20. [PubMed: 20233157]

7. Edwards KL, Clarke GP, Ransley JK, Cade JE. Serial cross-sectional analysis of prevalence of overweight and obese children between 1998 and 2003 in Leeds, UK, using routinely measured data. Public Health Nutr. 2011; 14:56-61. [PubMed: 20576200]

8. Ogden CL, Flegal KM, Carroll MD, Johnson CL. Prevalence and trends in overweight among US children and adolescents, 1999-2000. Jama. 2002; 288:1728-32. [PubMed: 12365956]

9. Lobstein T, Jackson-Leach R, Moodie ML, Hall KD, Gortmaker SL, Swinburn BA, et al. Child and adolescent obesity: part of a bigger picture. Lancet. 2015

10. Barlow SE, Dietz WH. Obesity evaluation and treatment: Expert Committee recommendations. The Maternal and Child Health Bureau, Health Resources and Services Administration and the Department of Health and Human Services. Pediatrics. 1998; 102:E29. [PubMed: 9724677]

11. Biro FM, Wien M. Childhood obesity and adult morbidities. Am J Clin Nutr. 2010; 91:1499s1505s. [PubMed: 20335542]

12. Daniels SR, Arnett DK, Eckel RH, Gidding SS, Hayman LL, Kumanyika S, et al. Overweight in children and adolescents: pathophysiology, consequences, prevention, and treatment. Circulation. 2005; 111:1999-2012. [PubMed: 15837955]

13. Luepker RV, Jacobs DR, Prineas RJ, Sinaiko AR. Secular trends of blood pressure and body size in a multi-ethnic adolescent population: 1986 to 1996. J Pediatr. 1999; 134:668-74. [PubMed: 10356132]

14. Singer C, Stancu P, Cosoveanu S, Botu A. Non-alcoholic Fatty liver disease in children. Curr Health Sci J. 2014; 40:170-6. [PubMed: 25729601]

15. Than NN, Newsome PN. A concise review of non-alcoholic fatty liver disease. Atherosclerosis. 2015; 239:192-202. [PubMed: 25617860]

16. Liang Y, Hou D, Zhao X, Wang L, Hu Y, Liu J, et al. Childhood obesity affects adult metabolic syndrome and diabetes. Endocrine. 2015

17. Krueger PM, Friedman EM. Sleep duration in the United States: a cross-sectional population-based study. Am J Epidemiol. 2009; 169:1052-63. [PubMed: 19299406]

18. Mindell JA, Meltzer LJ, Carskadon MA, Chervin RD. Developmental aspects of sleep hygiene: findings from the 2004 National Sleep Foundation Sleep in America Poll. Sleep Med. 2009; 10:771-9. [PubMed: 19285450]

19. Ogden CL, Carroll MD, Kit BK, Flegal KM. Prevalence of obesity and trends in body mass index among US children and adolescents, 1999-2010. Jama. 2012; 307:483-90. [PubMed: 22253364]

20. Wang Y, Beydoun MA. The obesity epidemic in the United States--gender, age, socioeconomic, racial/ethnic, and geographic characteristics: a systematic review and meta-regression analysis. Epidemiol Rev. 2007; 29:6-28. [PubMed: 17510091]

21. Chen X, Beydoun, Y MA. Wang. Is sleep duration associated with childhood obesity? A systematic review and meta-analysis. Obesity (Silver Spring). 2008; 16:265-74.

22. Fatima Y, Doi SA, Mamun AA. Longitudinal impact of sleep on overweight and obesity in children and adolescents: a systematic review and bias-adjusted meta-analysis. Obes Rev. 2015; 16:137-49. [PubMed: 25589359]

23. Franckle RL, Falbe J, Gortmaker S, Ganter C, Taveras EM, Land T, et al. Insufficient sleep among elementary and middle school students is linked with elevated soda consumption and other unhealthy dietary behaviors. Prev Med. 2015; 74:36-41. [PubMed: 25712328]

24. Marshall NS, Glozier N, Grunstein RR. Is sleep duration related to obesity? A critical review of the epidemiological evidence. Sleep Med Rev. 2008; 12:289-98. [PubMed: 18485764]

25. Miller AL, Lumeng JC, LeBourgeois MK. Sleep patterns and obesity in childhood. Curr Opin Endocrinol Diabetes Obes. 2015; 22:41-7. [PubMed: 25517022]

26. Taheri S, Thomas GN. Is sleep duration associated with obesity-where do U stand? Sleep Med Rev. 2008; 12:299-302. [PubMed: 18603219] 
27. Mavanji V, Teske JA, Billington CJ, Kotz CM. Elevated sleep quality and orexin receptor mRNA in obesity-resistant rats. Int J Obes (Lond). 2010; 34:1576-88. [PubMed: 20498657]

28. Weiss R, Bremer AA, Lustig RH. What is metabolic syndrome, and why are children getting it? Ann N Y Acad Sci. 2013; 1281:123-40. [PubMed: 23356701]

29. Zheng H, Berthoud HR. Neural systems controlling the drive to eat: mind versus metabolism. Physiology (Bethesda). 2008; 23:75-83. [PubMed: 18400690]

30. Cleator J, Judd P, James M, Abbott J, Sutton CJ, Wilding JP. Characteristics and perspectives of night-eating behaviour in a severely obese population. Clin Obes. 2014; 4:30-8. [PubMed: 25425130]

31. Appelhans BM, Fitzpatrick SL, Li H, Cail V, Waring ME, Schneider KL, et al. The home environment and childhood obesity in low-income households: indirect effects via sleep duration and screen time. BMC Public Health. 2014; 14:1160. [PubMed: 25381553]

32. Falbe J, Davison KK, Franckle RL, Ganter C, Gortmaker SL, Smith L, et al. Sleep duration, restfulness, and screens in the sleep environment. Pediatrics. 2015; 135:e367-75. [PubMed: 25560435]

33. Sijtsma A, Koller M, Sauer PJ, Corpeleijn E. Television, sleep, outdoor play and BMI in young children: the GECKO Drenthe cohort. Eur J Pediatr. 2014

34. Buxton OM, Marcelli E. Short and long sleep are positively associated with obesity, diabetes, hypertension, and cardiovascular disease among adults in the United States. Soc Sci Med. 2010; 71:1027-36. [PubMed: 20621406]

35. Hairston KG, Bryer-Ash M, Norris JM, Haffner S, Bowden DW, Wagenknecht LE. Sleep duration and five-year abdominal fat accumulation in a minority cohort: the IRAS family study. Sleep. 2010; 33:289-95. [PubMed: 20337186]

36. Nishiura C, Noguchi J, Hashimoto H. Dietary patterns only partially explain the effect of short sleep duration on the incidence of obesity. Sleep. 2010; 33:753-7. [PubMed: 20550015]

37. Taveras EM, Rifas-Shiman SL, Rich-Edwards JW, Gunderson EP, Stuebe AM, Mantzoros CS. Association of maternal short sleep duration with adiposity and cardiometabolic status at 3 years postpartum. Obesity (Silver Spring). 2011; 19:171-8. [PubMed: 20489690]

38. Nielsen LS, Danielsen KV, Sorensen TI. Short sleep duration as a possible cause of obesity: critical analysis of the epidemiological evidence. Obes Rev. 2011; 12:78-92. [PubMed: 20345429]

39. Grandner MA, Patel NP, Gehrman PR, Perlis ML, Pack AI. Problems associated with short sleep: bridging the gap between laboratory and epidemiological studies. Sleep Med Rev. 2010; 14:23947. [PubMed: 19896872]

40. Monasta L, Batty GD, Cattaneo A, Lutje V, Ronfani L, Van Lenthe FJ, et al. Early-life determinants of overweight and obesity: a review of systematic reviews. Obes Rev. 2010; 11:695708. [PubMed: 20331509]

41. Chaput JP, Leblanc C, Perusse L, Despres JP, Bouchard C, Tremblay A. Risk factors for adult overweight and obesity in the Quebec Family Study: have we been barking up the wrong tree? Obesity (Silver Spring). 2009; 17:1964-70. [PubMed: 19360005]

42. Chaput JP, McNeil J, Despres JP, Bouchard C, Tremblay A. Short sleep duration as a risk factor for the development of the metabolic syndrome in adults. Prev Med. 2013; 57:872-7. [PubMed: 24099879]

43. Chaput JP, Bouchard C, Tremblay A. Change in sleep duration and visceral fat accumulation over 6 years in adults. Obesity (Silver Spring). 2014; 22:E9-12. [PubMed: 24420871]

44. Cizza G, Marincola P, Mattingly M, Williams L, Mitler M, Skarulis M, et al. Treatment of obesity with extension of sleep duration: a randomized, prospective, controlled trial. Clin Trials. 2010; 7:274-85. [PubMed: 20423926]

45. Calamaro CJ, Park S, Mason TB, Marcus CL, Weaver TE, Pack A, et al. Shortened sleep duration does not predict obesity in adolescents. J Sleep Res. 2010; 19:559-66. [PubMed: 20545836]

46. Sun Y, Sekine M, Kagamimori S. Lifestyle and overweight among Japanese adolescents: the Toyama Birth Cohort Study. J Epidemiol. 2009; 19:303-10. [PubMed: 19776497]

47. Cespedes EM, Rifas-Shiman SL, Redline S, Gillman MW, Pena MM, Taveras EM. Longitudinal associations of sleep curtailment with metabolic risk in mid-childhood. Obesity (Silver Spring). 2014; 22:2586-92. [PubMed: 25234485] 
48. Bayer O, Rosario AS, Wabitsch M, von Kries R. Sleep duration and obesity in children: is the association dependent on age and choice of the outcome parameter? Sleep. 2009; 32:1183-9. [PubMed: 19750923]

49. Iglayreger HB, Peterson MD, Liu D, Parker CA, Woolford SJ, Sallinen Gafka BJ, et al. Sleep duration predicts cardiometabolic risk in obese adolescents. J Pediatr. 2014; 164:1085-1090. .e1. [PubMed: 24612904]

50. Meininger JC, Gallagher MR, Eissa MA, Nguyen TQ, Chan W. Sleep duration and its association with ambulatory blood pressure in a school-based, diverse sample of adolescents. Am J Hypertens. 2014; 27:948-55. [PubMed: 24487981]

51. Marshall NS, Glozier N, Grunstein RR. Reply to Taheri and Thomas: is sleep duration associated with obesity-U cannot be serious. Sleep Med Rev. 2008; 12:303-5. [PubMed: 18538598]

52. Nixon GM, Thompson JM, Han DY, Becroft DM, Clark PM, Robinson E, et al. Short sleep duration in middle childhood: risk factors and consequences. Sleep. 2008; 31:71-8. [PubMed: 18220080]

53. Cappuccio FP, Taggart FM, Kandala NB, Currie A, Peile E, Stranges S, et al. Meta-analysis of short sleep duration and obesity in children and adults. Sleep. 2008; 31:619-26. [PubMed: 18517032]

54. Gupta NK, Mueller WH, Chan W, Meininger JC. Is obesity associated with poor sleep quality in adolescents? Am J Hum Biol. 2002; 14:762-8. [PubMed: 12400037]

55. Patel SR, Hu FB. Short sleep duration and weight gain: a systematic review. Obesity (Silver Spring). 2008; 16:643-53. [PubMed: 18239586]

56. Spruyt K, Molfese DL, Gozal D. Sleep duration, sleep regularity, body weight, and metabolic homeostasis in school-aged children. Pediatrics. 2011; 127:e345-52. [PubMed: 21262888]

57. Flynn MA, McNeil DA, Maloff B, Mutasingwa D, Wu M, Ford C, et al. Reducing obesity and related chronic disease risk in children and youth: a synthesis of evidence with 'best practice' recommendations. Obes Rev. 2006; 7(Suppl 1):7-66. [PubMed: 16371076]

58. Sekine M, Yamagami T, Handa K, Saito T, Nanri S, Kawaminami K, et al. A dose-response relationship between short sleeping hours and childhood obesity: results of the Toyama Birth Cohort Study. Child Care Health Dev. 2002; 28:163-70. [PubMed: 11952652]

59. Padez C, Mourao I, Moreira P, Rosado V. Long sleep duration and childhood overweight/obesity and body fat. Am J Hum Biol. 2009; 21:371-6. [PubMed: 19189418]

60. Taveras EM, Rifas-Shiman SL, Oken E, Gunderson EP, Gillman MW. Short sleep duration in infancy and risk of childhood overweight. Arch Pediatr Adolesc Med. 2008; 162:305-11. [PubMed: 18391138]

61. Touchette E, Petit D, Tremblay RE, Boivin M, Falissard B, Genolini C, et al. Associations between sleep duration patterns and overweight/obesity at age 6. Sleep. 2008; 31:1507-14. [PubMed: 19014070]

62. Bhattacharjee R, Hakim F, Gozal D. Sleep, sleep-disordered breathing and lipid homeostasis: translational evidence from murine models and children. Clin Lipidol. 2012; 7:203-214. [PubMed: 22942904]

63. Bonuck K, Chervin RD, Howe LD. Sleep-disordered breathing, sleep duration, and childhood overweight: a longitudinal cohort study. J Pediatr. 2015; 166:632-9. [PubMed: 25499598]

64. Corbo GM, Fuciarelli F, Foresi A, De Benedetto F. Snoring in children: association with respiratory symptoms and passive smoking. Bmj. 1989; 299:1491-4. [PubMed: 2514859]

65. Gislason T, Benediktsdottir B. Snoring, apneic episodes, and nocturnal hypoxemia among children 6 months to 6 years old. An epidemiologic study of lower limit of prevalence. Chest. 1995; 107:963-6. [PubMed: 7705162]

66. Capdevila OS, Kheirandish-Gozal L, Dayyat E, Gozal D. Pediatric obstructive sleep apnea: complications, management, and long-term outcomes. Proc Am Thorac Soc. 2008; 5:274-82. [PubMed: 18250221]

67. Gozal D, Kheirandish-Gozal L. The multiple challenges of obstructive sleep apnea in children: morbidity and treatment. Curr Opin Pediatr. 2008; 20:654-8. [PubMed: 19005334] 
68. Kheirandish-Gozal L, Bhattacharjee R, Gozal D. Autonomic alterations and endothelial dysfunction in pediatric obstructive sleep apnea. Sleep Med. 2010; 11:714-20. [PubMed: 20620107]

69. Kheirandish-Gozal L, Kim J, Goldbart AD, Gozal D. Novel pharmacological approaches for treatment of obstructive sleep apnea in children. Expert Opin Investig Drugs. 2013; 22:71-85.

70. Hakim F, Gozal D, Kheirandish-Gozal L. Sympathetic and catecholaminergic alterations in sleep apnea with particular emphasis on children. Front Neurol . 2012; 3:7. [PubMed: 22319509]

71. Kheirandish-Gozal L, Peris E, Gozal D. Vitamin D levels and obstructive sleep apnoea in children. Sleep Med. 2014; 15:459-63. [PubMed: 24684979]

72. Dayyat E, Kheirandish-Gozal L, Gozal D. Childhood Obstructive Sleep Apnea: One or Two Distinct Disease Entities? Sleep Med Clin. 2007; 2:433-444. [PubMed: 18769509]

73. Ferreira AM, Clemente V, Gozal D, Gomes A, Pissarra C, Cesar H, et al. Snoring in Portuguese primary school children. Pediatrics. 2000; 106:E64. [PubMed: 11061801]

74. Jeans WD, Fernando DC, Maw AR, Leighton BC. A longitudinal study of the growth of the nasopharynx and its contents in normal children. Br J Radiol. 1981; 54:117-21. [PubMed: 7459548]

75. O'Brien LM, Holbrook CR, Mervis CB, Klaus CJ, Bruner JL, Raffield TJ, et al. Sleep and neurobehavioral characteristics of 5- to 7-year-old children with parentally reported symptoms of attention-deficit/hyperactivity disorder. Pediatrics. 2003; 111:554-63. [PubMed: 12612236]

76. Owen GO, Canter RJ, Robinson A. Snoring, apnoea and ENT symptoms in the paediatric community. Clin Otolaryngol Allied Sci. 1996; 21:130-4. [PubMed: 8735397]

77. Katz ES, D'Ambrosio CM. Pathophysiology of pediatric obstructive sleep apnea. Proc Am Thorac Soc. 2008; 5:253-62. [PubMed: 18250219]

78. Arens R, Sin S, Willen S, Bent J, Parikh SR, Freeman K, et al. Rhino-sinus involvement in children with obstructive sleep apnea syndrome. Pediatr Pulmonol. 2010; 45:993-8. [PubMed: 20648667]

79. Mitchell EA, Thompson JM. Snoring in the first year of life. Acta Paediatr. 2003; 92:425-9. [PubMed: 12801107]

80. Redline S, Tishler PV, Hans MG, Tosteson TD, Strohl KP, Spry K. Racial differences in sleepdisordered breathing in African-Americans and Caucasians. Am J Respir Crit Care Med. 1997; 155:186-92. [PubMed: 9001310]

81. Rosen CL, Larkin EK, Kirchner HL, Emancipator JL, Bivins SF, Surovec SA, et al. Prevalence and risk factors for sleep-disordered breathing in 8- to 11-year-old children: association with race and prematurity. J Pediatr. 2003; 142:383-9. [PubMed: 12712055]

82. Urschitz MS, Guenther A, Eitner S, Urschitz-Duprat PM, Schlaud M, Ipsiroglu OS, et al. Risk factors and natural history of habitual snoring. Chest. 2004; 126:790-800. [PubMed: 15364758]

83. Arens R, Muzumdar H. Childhood obesity and obstructive sleep apnea syndrome. J Appl Physiol (1985). 2010; 108:436-44. [PubMed: 19875714]

84. Redline S, Tishler PV, Schluchter M, Aylor J, Clark K, Graham G. Risk factors for sleepdisordered breathing in children. Associations with obesity, race, and respiratory problems. Am J Respir Crit Care Med. 1999; 159:1527-32.

85. Spilsbury JC, Storfer-Isser A, Rosen CL, Redline S. Remission and incidence of obstructive sleep apnea from middle childhood to late adolescence. Sleep. 2015; 38:23-9. [PubMed: 25325456]

86. Bixler EO, Vgontzas AN, Lin HM, Liao D, Calhoun S, Vela-Bueno A, et al. Sleep disordered breathing in children in a general population sample: prevalence and risk factors. Sleep. 2009; 32:731-6. [PubMed: 19544748]

87. Dayyat E, Kheirandish-Gozal L, Sans Capdevila O, Maarafeya MM, Gozal D. Obstructive sleep apnea in children: relative contributions of body mass index and adenotonsillar hypertrophy. Chest. 2009; 136:137-44. [PubMed: 19225059]

88. Kahn A, Mozin MJ, Rebuffat E, Sottiaux M, Burniat W, Shepherd S, et al. Sleep pattern alterations and brief airway obstructions in overweight infants. Sleep. 1989; 12:430-8. [PubMed: 2799216]

89. Kalra M, Inge T, Garcia V, Daniels S, Lawson L, Curti R, et al. Obstructive sleep apnea in extremely overweight adolescents undergoing bariatric surgery. Obes Res. 2005; 13:1175-9. [PubMed: 16076986] 
90. Kohler MJ, Thormaehlen S, Kennedy JD, Pamula Y, van den Heuvel CJ, Lushington K, et al. Differences in the association between obesity and obstructive sleep apnea among children and adolescents. J Clin Sleep Med. 2009; 5:506-11. [PubMed: 20465015]

91. Mitchell RB, Boss EF. Pediatric obstructive sleep apnea in obese and normal-weight children: impact of adenotonsillectomy on quality-of-life and behavior. Dev Neuropsychol. 2009; 34:65061. [PubMed: 20183725]

92. Shine NP, Coates HL, Lannigan FJ. Obstructive sleep apnea, morbid obesity, and adenotonsillar surgery: a review of the literature. Int J Pediatr Otorhinolaryngol. 2005; 69:1475-82. [PubMed: 16171876]

93. Verhulst SL, Franckx H, Van Gaal L, De Backer W, Desager K. The effect of weight loss on sleepdisordered breathing in obese teenagers. Obesity (Silver Spring). 2009; 17:1178-83. [PubMed: 19265797]

94. Wing YK, Hui SH, Pak WM, Ho CK, Cheung A, Li AM, et al. A controlled study of sleep related disordered breathing in obese children. Arch Dis Child. 2003; 88:1043-7. [PubMed: 14670764]

95. Horner RL, Mohiaddin RH, Lowell DG, Shea SA, Burman ED, Longmore DB, et al. Sites and sizes of fat deposits around the pharynx in obese patients with obstructive sleep apnoea and weight matched controls. Eur Respir J. 1989; 2:613-22. [PubMed: 2776867]

96. White DP, Lombard RM, Cadieux RJ, Zwillich CW. Pharyngeal resistance in normal humans: influence of gender, age, and obesity. J Appl Physiol (1985). 1985; 58:365-71. [PubMed: 3980345]

97. Naimark A, Cherniack RM. Compliance of the respiratory system and its components in health and obesity. J Appl Physiol. 1960; 15:377-82. [PubMed: 14425845]

98. Beebe DW, Lewin D, Zeller M, McCabe M, MacLeod K, Daniels SR, et al. Sleep in overweight adolescents: shorter sleep, poorer sleep quality, sleepiness, and sleep-disordered breathing. J Pediatr Psychol. 2007; 32:69-79. [PubMed: 16467311]

99. Chervin RD, Weatherly RA, Ruzicka DL, Burns JW, Giordani BJ, Dillon JE, et al. Subjective sleepiness and polysomnographic correlates in children scheduled for adenotonsillectomy vs other surgical care. Sleep. 2006; 29:495-503. [PubMed: 16676783]

100. Gozal D, Wang M, Pope DW Jr. Objective sleepiness measures in pediatric obstructive sleep apnea. Pediatrics. 2001; 108:693-7. [PubMed: 11533338]

101. Melendres MC, Lutz JM, Rubin ED, Marcus CL. Daytime sleepiness and hyperactivity in children with suspected sleep-disordered breathing. Pediatrics. 2004; 114:768-75. [PubMed: 15342852]

102. Tauman R, O'Brien LM, Holbrook CR, Gozal D. Sleep pressure score: a new index of sleep disruption in snoring children. Sleep. 2004; 27:274-8. [PubMed: 15124722]

103. Spruyt K, Sans Capdevila O, Serpero LD, Kheirandish-Gozal L, Gozal D. Dietary and physical activity patterns in children with obstructive sleep apnea. J Pediatr. 2010; 156:724-30. 730.e1-730.e3. [PubMed: 20138306]

104. Gozal D, Kheirandish-Gozal L. Obesity and excessive daytime sleepiness in prepubertal children with obstructive sleep apnea. Pediatrics. 2009; 123:13-8. [PubMed: 19117855]

105. Gozal D. Sleep, sleep disorders and inflammation in children. Sleep Med. 2009; 10(Suppl 1):S12-6. [PubMed: 19647481]

106. Kim J, Gozal D, Bhattacharjee R, Kheirandish-Gozal L. TREM-1 and pentraxin-3 plasma levels and their association with obstructive sleep apnea, obesity, and endothelial function in children. Sleep. 2013; 36:923-31. [PubMed: 23729936]

107. Kim J, Hakim F, Kheirandish-Gozal L, Gozal D. Inflammatory pathways in children with insufficient or disordered sleep. Respir Physiol Neurobiol. 2011; 178:465-74. [PubMed: 21569868]

108. Gozal D, Serpero LD, Kheirandish-Gozal L, Capdevila OS, Khalyfa A, Tauman R. Sleep measures and morning plasma TNF-alpha levels in children with sleep-disordered breathing. Sleep. 2010; 33:319-25. [PubMed: 20337189]

109. Gozal D, Serpero LD, Sans Capdevila O, Kheirandish-Gozal L. Systemic inflammation in nonobese children with obstructive sleep apnea. Sleep Med. 2008; 9:254-9. [PubMed: 17825619] 
110. Khalyfa A, Capdevila OS, Buazza MO, Serpero LD, Kheirandish-Gozal L, Gozal D. Genomewide gene expression profiling in children with non-obese obstructive sleep apnea. Sleep Med. 2009; 10:75-86. [PubMed: 18261956]

111. Kim J, Bhattacharjee R, Snow AB, Capdevila OS, Kheirandish-Gozal L, Gozal D. Myeloidrelated protein 8/14 levels in children with obstructive sleep apnoea. Eur Respir J. 2010; 35:84350. [PubMed: 19608587]

112. Tauman R, Ivanenko A, O'Brien LM, Gozal D. Plasma C-reactive protein levels among children with sleep-disordered breathing. Pediatrics. 2004; 113:e564-9. [PubMed: 15173538]

113. Gozal D, Capdevila OS, Kheirandish-Gozal L. Metabolic alterations and systemic inflammation in obstructive sleep apnea among nonobese and obese prepubertal children. Am J Respir Crit Care Med. 2008; 177:1142-9. [PubMed: 18276939]

114. Kheirandish-Gozal L, Sans Capdevila O, Kheirandish E, Gozal D. Elevated serum aminotransferase levels in children at risk for obstructive sleep apnea. Chest. 2008; 133:92-9. [PubMed: 18187742]

115. Spruyt K, Gozal D. Mr. Pickwick and his child went on a field trip and returned almost empty handed... What we do not know and imperatively need to learn about obesity and breathing during sleep in children! Sleep Med Rev. 2008; 12:335-8. [PubMed: 18790409]

116. Tsaoussoglou M, Bixler EO, Calhoun S, Chrousos GP, Sauder K, Vgontzas AN. Sleep-disordered breathing in obese children is associated with prevalent excessive daytime sleepiness, inflammation, and metabolic abnormalities. J Clin Endocrinol Metab. 2010; 95:143-50. [PubMed: 19926716]

117. Tan HL, Gozal D, Kheirandish-Gozal L. Obstructive sleep apnea in children: a critical update. Nat Sci Sleep. 2013; 5:109-23. [PubMed: 24109201]

118. Kheirandish-Gozal L, Gileles-Hillel A, Alonso-Alvarez ML, Peris E, Bhattacharjee R, TeranSantos J, et al. Effects of adenotonsillectomy on plasma inflammatory biomarkers in obese children with obstructive sleep apnea: A community-based study. Int J Obes (Lond). 2015

119. Gileles-Hillel A, Alonso-Alvarez ML, Kheirandish-Gozal L, Peris E, Cordero-Guevara JA, Teran-Santos J, et al. Inflammatory markers and obstructive sleep apnea in obese children: the NANOS study. Mediators Inflamm . 2014; 2014:605280. [PubMed: 24991089]

120. Cox AJ, West NP, Cripps AW. Obesity, inflammation, and the gut microbiota. Lancet Diabetes Endocrinol. 2015; 3:207-15. [PubMed: 25066177]

121. Hansen TH, Gobel RJ, Hansen T, Pedersen O. The gut microbiome in cardio-metabolic health. Genome Med . 2015; 7:33. [PubMed: 25825594]

122. Maranduba CM, De Castro SB, de Souza GT, Rossato C, da Guia FC, Valente MA, et al. Intestinal Microbiota as Modulators of the Immune System and Neuroimmune System: Impact on the Host Health and Homeostasis. J Immunol Res . 2015; 2015:931574. [PubMed: 25759850]

123. Moreno-Indias I, Torres M, Montserrat JM, Sanchez-Alcoholado L, Cardona F, Tinahones FJ, et al. Intermittent hypoxia alters gut microbiota diversity in a mouse model of sleep apnoea. Eur Respir J. 2015; 45:1055-65. [PubMed: 25537565]

124. Kheirandish-Gozal L, Peris E, Wang Y, Tamae Kakazu M, Khalyfa A, Carreras A, et al. Lipopolysaccharide-binding protein plasma levels in children: effects of obstructive sleep apnea and obesity. J Clin Endocrinol Metab. 2014; 99:656-63. [PubMed: 24276451]

125. Bhattacharjee R, Kheirandish-Gozal L, Spruyt K, Mitchell RB, Promchiarak J, Simakajornboon $\mathrm{N}$, et al. Adenotonsillectomy outcomes in treatment of obstructive sleep apnea in children: a multicenter retrospective study. Am J Respir Crit Care Med. 2010; 182:676-83. [PubMed: 20448096]

126. Tauman R, Gulliver TE, Krishna J, Montgomery-Downs HE, O'Brien LM, Ivanenko A, et al. Persistence of obstructive sleep apnea syndrome in children after adenotonsillectomy. J Pediatr. 2006; 149:803-8. [PubMed: 17137896]

127. Cortese S, Vincenzi B. Obesity and ADHD: clinical and neurobiological implications. Curr Top Behav Neurosci. 2012; 9:199-218. [PubMed: 21845534]

128. Kalarchian MA, Marcus MD. Psychiatric comorbidity of childhood obesity. Int Rev Psychiatry. 2012; 24:241-6. [PubMed: 22724645] 
129. Puder JJ, Munsch S. Psychological correlates of childhood obesity. Int J Obes (Lond). 2010; 34(Suppl 2):S37-43. [PubMed: 21151145]

130. Liang J, Matheson BE, Kaye WH, Boutelle KN. Neurocognitive correlates of obesity and obesityrelated behaviors in children and adolescents. Int J Obes (Lond). 2014; 38:494-506. [PubMed: 23913029]

131. Gozal D. Sleep-disordered breathing and school performance in children. Pediatrics. 1998; 102:616-20. [PubMed: 9738185]

132. Gozal D, Pope DW Jr. Snoring during early childhood and academic performance at ages thirteen to fourteen years. Pediatrics. 2001; 107:1394-9. [PubMed: 11389263]

133. Spruyt K, Gozal D. A mediation model linking body weight, cognition, and sleep-disordered breathing. Am J Respir Crit Care Med. 2012; 185:199-205. [PubMed: 22071385]

134. Gregory AM, Sadeh A. Sleep, emotional and behavioral difficulties in children and adolescents. Sleep Med Rev. 2012; 16:129-36. [PubMed: 21676633]

135. Maski KP, Kothare SV. Sleep deprivation and neurobehavioral functioning in children. Int J Psychophysiol. 2013; 89:259-64. [PubMed: 23797147]

136. Spruyt K, Gozal D. Sleep disturbances in children with attention-deficit/hyperactivity disorder. Expert Rev Neurother. 2011; 11:565-77. [PubMed: 21469929]

137. Urbain C, Galer S, Van Bogaert P, Peigneux P. Pathophysiology of sleep-dependent memory consolidation processes in children. Int J Psychophysiol. 2013; 89:273-83. [PubMed: 23810995]

138. Yoon SY, Jain U, Shapiro C. Sleep in attention-deficit/hyperactivity disorder in children and adults: past, present, and future. Sleep Med Rev. 2012; 16:371-88. [PubMed: 22033171]

139. Ptacek R, Kuzelova H, Stefano GB, Raboch J, Sadkova T, Goetz M, et al. Disruptive patterns of eating behaviors and ADHD. Med Sci Monit. 2014; 20:608-13. [PubMed: 24727744] 


\section{Summary}

The prevalence and severity of obesity in children and adolescents has dramatically increased worldwide along with obesity-associated morbidities particularly affecting the metabolic and cardiovascular systems. The role of sleep habits, e.g., duration and regularity, and their impact on accelerated weight accrual mechanisms is slowly emerging but the picture is far from complete. Similarly, obesity and obstructive sleep apnea syndrome appear to contribute to the initiation and progression of each other, possibly via their shared effects on the recruitment and potentiation of inflammatory pathways (Figure 2). Future efforts aimed at intervention will undoubtedly shed increased light into the roles played by sleep in obesity. Irrespectively, we cannot afford to wait for the results of such studies, such that implementation of public health campaigns that promote the " $3 \mathrm{H}$ ", healthy sleep, healthy food, and healthy exercise habits, particularly among children, will not only do no harm but have the potential to slow down the progression of the rampant obesity epidemic that affects humans everywhere. 

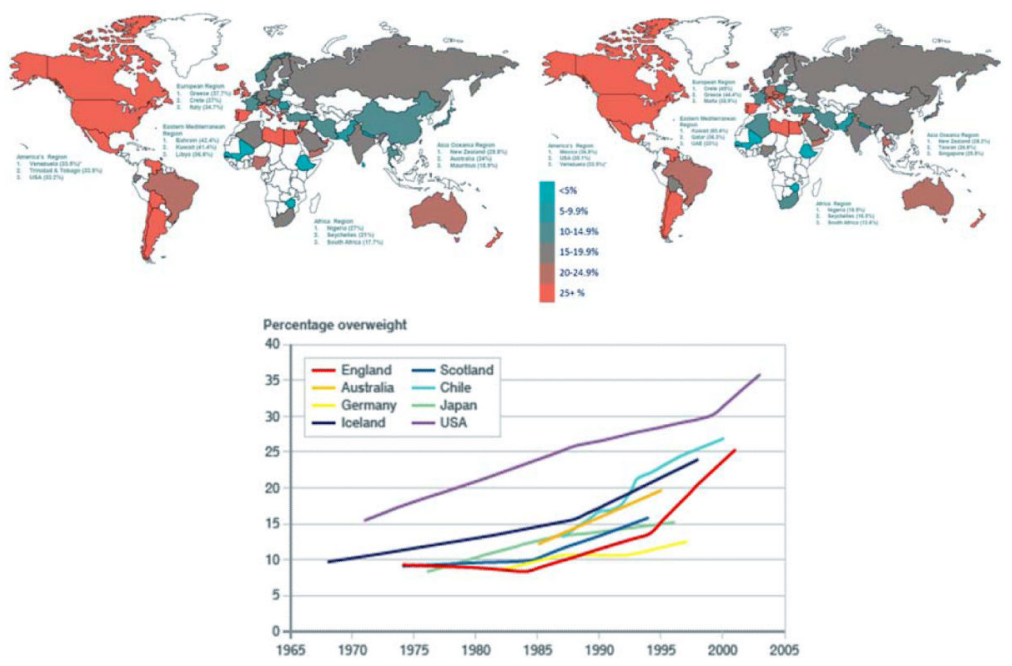

Figure 1.

Prevalence trends in pediatric overweight and obesity around the world in girls (left upper panel) and boys (right upper panel), as well as yearly trends from 1965 to 2005 in different countries.

Modified from: http://www.worldobesity.org/ and https://www.gov.uk/government/uploads/ system/uploads/attachment_data/file/295685/07-926A3-obesity-international.pdf 


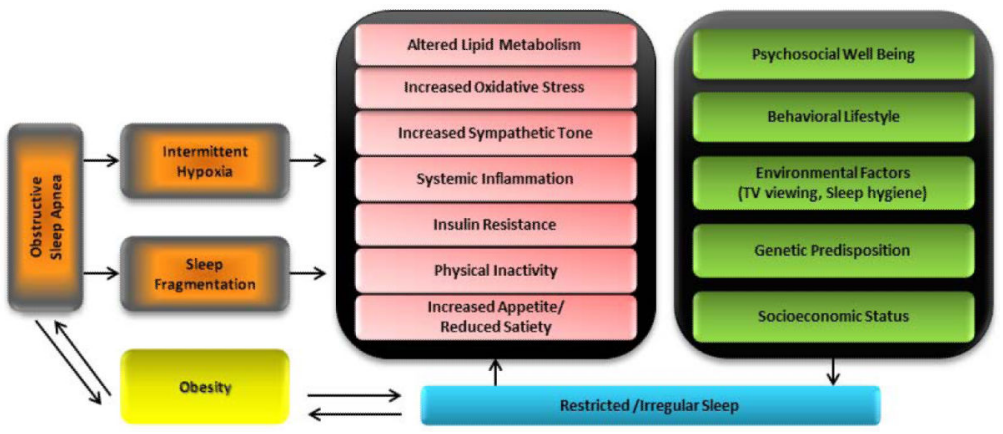

Figure 2.

Schematic diagram illustrating the convergence and interdependence of alterations in sleep duration and regularity and perturbations in sleep associated with OSA into multiple processes that promote obesity, and vice-versa. 